Article

\title{
Yeast Extract and Silver Nitrate Induce the Expression of Phenylpropanoid Biosynthetic Genes and Induce the Accumulation of Rosmarinic Acid in Agastache rugosa Cell Culture
}

\author{
Woo Tae Park ${ }^{1,+}{ }^{+}$, Mariadhas Valan Arasu ${ }^{2,+}$, Naif Abdullah Al-Dhabi ${ }^{2}$, Sun Kyung Yeo ${ }^{1}$, \\ Jin Jeon ${ }^{1}$, Jong Seok Park ${ }^{3}$, Sook Young Lee ${ }^{4, *}$ and Sang Un Park ${ }^{1, *}$ \\ 1 Department of Crop Science, Chungnam National University, 99 Daehak-ro, Yuseong-gu, Daejeon 34134, \\ Korea; harusarinamu@gmail.com (W.T.P.); agape0619@naver.com (S.K.Y.); jeonjin519@gmail.com (J.J.) \\ 2 Department of Botany and Microbiology, Addiriyah Chair for Environmental Studies, College of Science, \\ King Saud University, P. O. Box 2455, Riyadh 11451, Saudi Arabia; mvalanarasu@gmail.com (M.V.A.); \\ naldhabi@ksu.edu.sa (N.A.A.) \\ 3 Department of Horticulture, Chungnam National University, 99 Daehak-ro, Yuseong-gu, Daejeon 34134, \\ Korea; jongseok@cnu.ac.kr \\ 4 Regional Innovation Center for Dental Science \& Engineering, Chosun University, 309 Pilmun-daero, \\ Dong-gu, Gwangju 501-759, Korea \\ * Correspondence: seedbank2001@hanmail.net (S.Y.L.); supark@cnu.ac.kr (S.U.P.); \\ Tel.: +82-10-8610-6739 (S.Y.L.); +82-42-821-6730 (S.U.P.); \\ Fax: +82-62-232-6896 (S.Y.L.); +82-42-822-2631 (S.U.P.) \\ + These authors contributed equally to this work.
}

Academic Editor: Tobias A. M. Gulder

Received: 10 January 2016 ; Accepted: 21 March 2016 ; Published: 29 March 2016

\begin{abstract}
The present study aimed to investigate the role of yeast extract and silver nitrate on the enhancement of phenylpropanoid pathway genes and accumulation of rosmarinic acid in Agastache rugosa cell cultures. The treatment of cell cultures with yeast extract $(500 \mathrm{mg} / \mathrm{L})$ and silver nitrate $(30 \mathrm{mg} / \mathrm{L})$ for varying times enhanced the expression of genes in the phenylpropanoid pathway and the production of rosmarinic acid. The results indicated that the expression of $R A S$ and HPPR was proportional to the amount of yeast extract and silver nitrate. The transcript levels of $H P P R$ under yeast extract treatment were 1.84-, 1.97-, and 2.86-fold higher than the control treatments after 3,6 , and $12 \mathrm{~h}$, respectively, whereas $P A L$ expression under silver nitrate treatment was 52.31-fold higher than in the non-treated controls after $24 \mathrm{~h}$ of elicitation. The concentration of rosmarinic acid was directly proportional to the concentration of the applied elicitors. Yeast extract supplementation documented the highest amount of rosmarinic acid at $4.98 \mathrm{mg} / \mathrm{g}$, whereas silver nitrate addition resulted in a comparatively lower amount of rosmarinic acid at $0.65 \mathrm{mg} / \mathrm{g}$. In conclusion, addition of yeast extract to the cell cultures enhanced the accumulation of rosmarinic acid, which was evidenced by the expression levels of the phenylpropanoid biosynthetic pathway genes in A. rugosa.
\end{abstract}

Keywords: Agastache rugose; yeast extract; silver nitrate; phenylpropanoid biosynthetic genes; rosmarinic acid

\section{Introduction}

Production of useful metabolites such as alkaloids, flavanoids, phenolic compounds and other phytochemicals from in vitro plant cell cultures has attracted many pharmaceutical industries because of advances in technology for the bulk production of important novel metabolites [1,2]. Many modern methods, including precursor feeding, elicitation, and membrane permeabilization, have been applied 
to enhance the level of secondary metabolites synthesized in plant cell cultures [3-5]. In vitro plant cell cultures, the use of biotic (yeast, bacteria, and fungi) and abiotic (jasmonic acid, arachidonic acid, methyl jasmonate, and other chemicals) elicitors has been reported to stimulate the production rate of useful secondary metabolites at a commercial scale in shorter production periods [6]. Elicitors derived from fungi were used to stimulate the production of secondary metabolite. This strategy is efficient in stimulating the synthesis of important secondary metabolites, such as flavonoids [7], alkaloids [8], terpenoids [9], and coumarin derivatives [10]. Rosmarinic acid produced by the phenylpropanoid pathway in medicinal plants exhibits antiviral, antimicrobial, anti-inflammatory, antioxidant, antihypertensive, and antiatherogenic activities [11-18].

The presumed phenylpropanoid metabolic biosynthetic pathway for the synthesis of rosmarinic acid in plants is presented in Figure 1. Phenylalanine is converted into cinnamic acid, 4-coumaric acid, and other metabolites by three enzymes: phenylalanine ammonia-lyase (PAL), cinnamate 4-hydroxylase $(\mathrm{C} 4 \mathrm{H})$, and 4-coumarate:CoA ligase (4CL) [19]. The activated intermediate molecule, 4-coumaroyl-CoA, serves as a precursor for the formation of a number of natural products, such as lignin, coumarin, flavonoids, and cell wall-bound phenolics. Further, 4-coumaroyl-CoA reacts with 4-hydroxyphenyllactic acid to form 4-coumaroyl-4'-hydroxyphenyllactic acid. Finally, rosmarinic acid is derived from the hydroxylation reaction between the compounds caffeoyl-4-hydroxyphenyllactic acid and 4-coumarotil-3,4-dihydroxyphenyllactic acid [20,21].

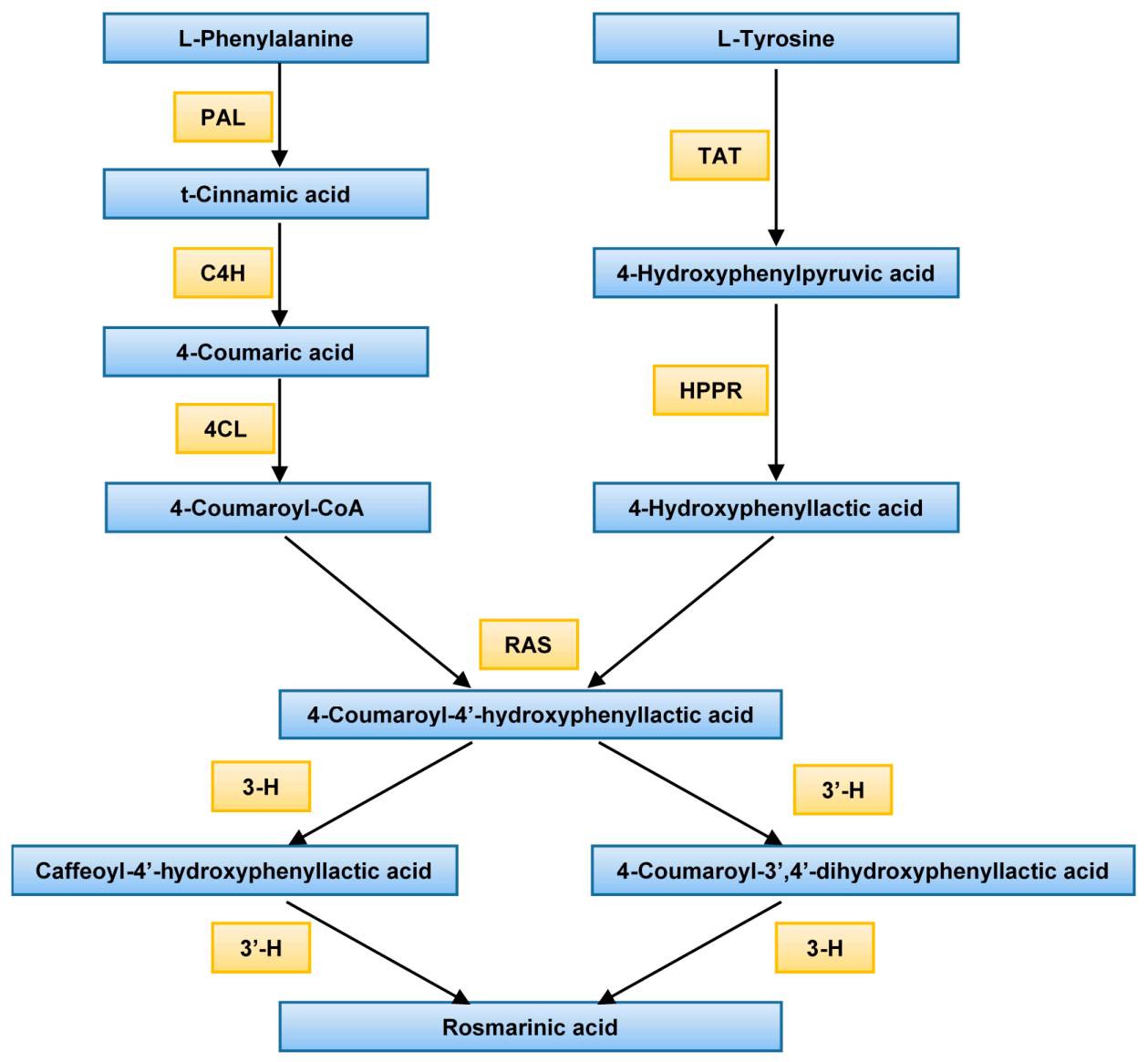

Figure 1. Proposed biosynthetic pathway of rosmarinic acid. PAL, phenylalanine ammonia-lyase; $\mathrm{C} 4 \mathrm{H}$, cinnamate 4-hydroxylase; 4CL, 4-coumarate CoA ligase; TAT, tyrosine amino transferase; HPPR, hydroxyl phenylpyruvate reductase; RAS, rosmarinic acid synthase (hydroxycinnamoyl-CoA:hydroxyphenyllactate hydroxycinnamoyl transferase); 3-H, 3-hydroxylase; 3'-H, 3'-hydroxylase. 
In general, higher amounts of rosmarinic acid are present in undifferentiated tissue-cultured cells than in the wild plants [22]. The first plant cell suspension cultures found to accumulate rosmarinic acid were derived from Coleus blumei [22,23] and rosmarinic acid accumulated up to $20 \%$ of the cell dry weight [24]. In cell suspension cultures of Agastache rugosa grown in B5 cultivation medium with $2 \mathrm{mg} / \mathrm{L}$ 2,4-D, and $0.1 \mathrm{mg} / \mathrm{L}$ 6-benzylaminopurine, higher cell growth and rosmarinic acid production occurred compared to $2 \mathrm{mg} / \mathrm{L}$ 2,4-D single treatment [25], whereas Ocimum basilicum documented $10 \mathrm{mg} / \mathrm{g}$ dry weight rosmarinic acid [26]. Rosmarinic acid content increased when the cells were treated with a benzothiadiazole elicitor preparation in A. rugosa [27]. Rosmarinic acid accumulation was also induced by the addition of yeast extract to suspension cultures of Lithospermum erythrorhizon [28] and Orthosiphon aristatus [29]. Rosmarinic acid accumulation as well as total phenolic content of Salvia miltiorrhiza hairy roots was increased by both elicitors (yeast extract and silver nitrate), but more significantly by yeast extract [30].

Agastache rugosa, also known as Korean mint, is a perennial herb that belongs to the mint family (Labiatae). Rosmarinic acid is considered to be the main phenylpropanoid and has been proven to contribute to the medicinal potential of A. rugosa. The present study was conducted to examine the effects of yeast extract and silver nitrate on the enhancement of rosmarinic acid in cell cultures of A. rugosa, as well as to determine whether the addition of yeast extract and silver nitrate influence the phenylpropanoid biosynthetic pathway genes in A. rugosa.

\section{Results}

\subsection{Gene Expression}

Ten-day-old cell suspension cultures of $A$. rugosa were treated with various concentrations of yeast extract or silver nitrate and the changes in the expression levels of rosmarinic acid biosynthetic genes were investigated. The expression levels of phenypropanoid genes under various concentrations of yeast extract and silver nitrate are presented in Figures 2 and 3. The yeast extract treatments influenced greatly the expression of different genes in the cell suspensions of A. rugose (Figure 2). In particular, $500 \mathrm{mg} / \mathrm{L}$ yeast extract induced higher levels of mRNA for all genes compared to other concentrations. RAS transcription levels were directly proportional to the concentration of yeast extract up to $500 \mathrm{mg} / \mathrm{L}$. The highest and lowest levels of $R A S$ transcript were obtained in cell suspensions treated with $500 \mathrm{mg} / \mathrm{L}$ and $1000 \mathrm{mg} / \mathrm{L}$ yeast extract, respectively. The results of HPPR expression were similar to that of the RAS gene. Although the highest HPPR transcript level was in suspension cells treated with $500 \mathrm{mg} / \mathrm{L}$ yeast extract, the increase was not significant. The results indicated that the expression level of $C 4 H, P A L$ and TAT were maximum at $500 \mathrm{mg} / \mathrm{L}$ yeast extract, whereas the lowest transcript levels were found in cell suspensions treated with $1000 \mathrm{mg} / \mathrm{L}$ yeast extract.

In another experiment, silver nitrate significantly affected the expression levels of genes in cell suspensions of $A$. rugosa at concentrations less than one-tenth that of yeast extract (Figure 3 ). The transcript levels of most of the genes increased upon silver nitrate treatments. In particular, cell suspensions treated with $30 \mathrm{mg} / \mathrm{L}$ silver nitrate showed the highest levels of mRNA for all tested genes, but the expression of $R A S$ decreased slightly at a concentration of $30 \mathrm{mg} / \mathrm{L}$ silver nitrate. At $30 \mathrm{mg} / \mathrm{L}$, the transcript levels of HPPR and TAT were 1.87- and 3.05-fold higher than the non-treated control. Furthermore, TAT expression increased sharply in cell suspensions treated with 10, 20, and $30 \mathrm{mg} / \mathrm{L}$ silver nitrate up to levels 2.75- to 4.35-fold higher than that in the control. There was no significant change in the transcript levels of PAL in suspension cells treated with $20 \mathrm{mg} / \mathrm{L}$ silver nitrate, whereas the highest levels of PAL transcript were observed in cell suspensions treated with $30 \mathrm{mg} / \mathrm{L}$ silver nitrate, reaching levels 3.54-fold higher than those in the control. 


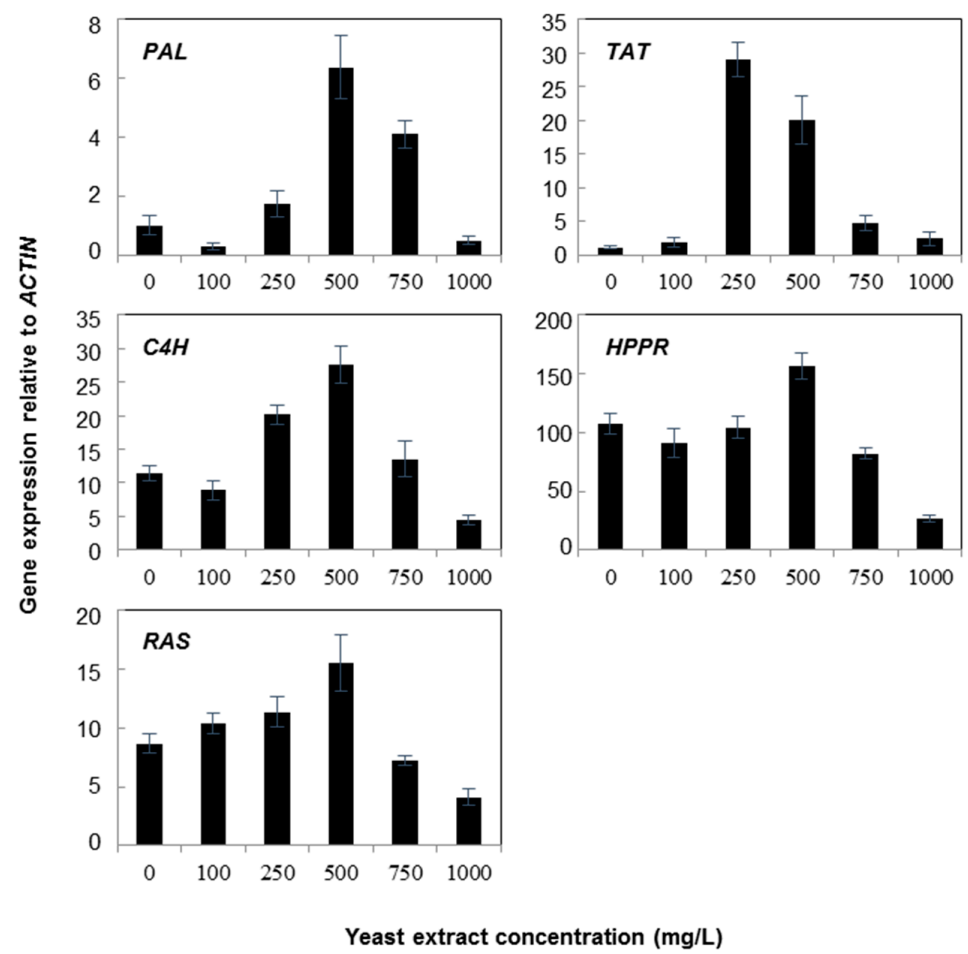

Figure 2. Expression of rosmarinic acid biosynthetic genes in Agastache rugosa calli treated with various concentrations of yeast extract for $72 \mathrm{~h}$. Transcription levels for each gene were analyzed relative to that of ACTIN. Error bars show standard deviation values.

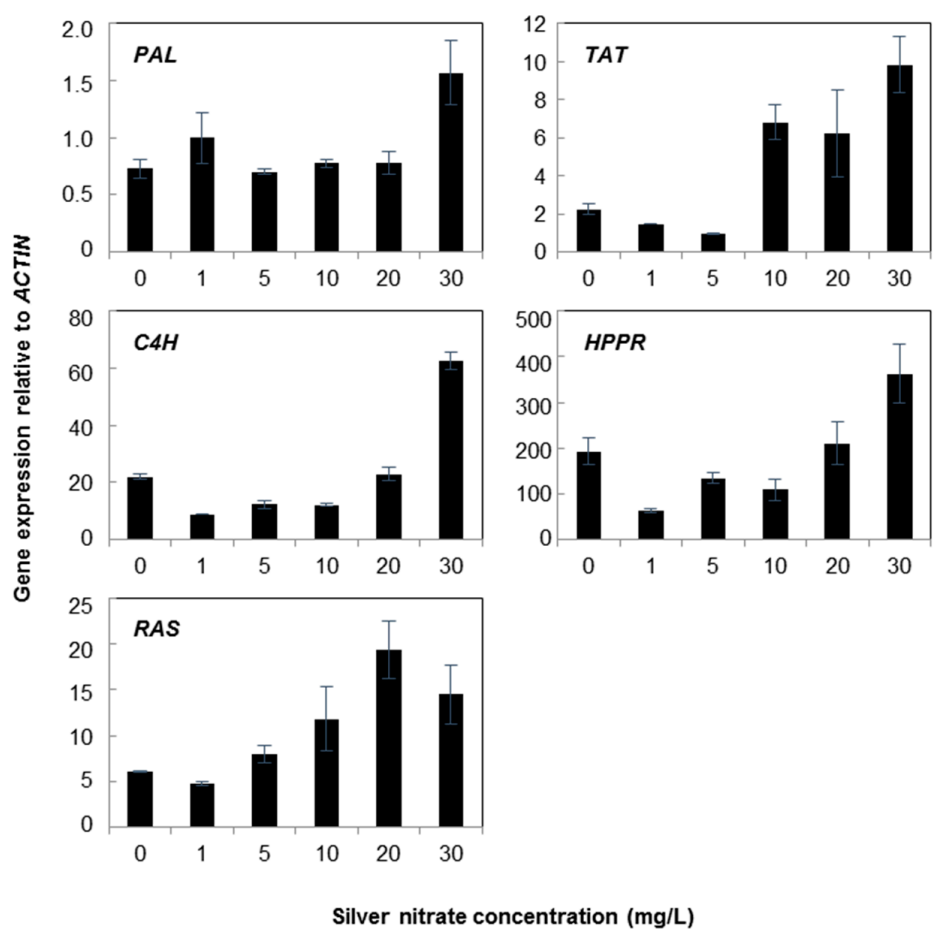

Figure 3. Expression of rosmarinic acid biosynthetic genes in Agastache rugosa calli treated with various concentrations of silver nitrate for $72 \mathrm{~h}$. Transcription levels for each gene were analyzed relative to that of ACTIN. Error bars show standard deviation values. 
The optimum concentrations of yeast extract and silver nitrate, $500 \mathrm{mg} / \mathrm{L}$ and $30 \mathrm{mg} / \mathrm{L}$ respectively, were used to treat ten-day-old cell suspensions of $A$. rugosa, and their influence on rosmarinic acid biosynthetic genes was investigated over a period of time from 0 to $72 \mathrm{~h}$. The results documented that RAS expression levels increased from $3 \mathrm{~h}$ after the yeast extract treatment until $48 \mathrm{~h}$, followed by a dramatic decrease $72 \mathrm{~h}$ after the yeast extract treatment (Figure 4 ). The highest level of $R A S$ expression was observed at $48 \mathrm{~h}$ and showed levels 10.95 times higher than that in the control treatment. However, the expression levels of HPPR were 1.84-, 1.97-, and 2.86-fold higher at 3, 6, and $12 \mathrm{~h}$, respectively, and the expression was slightly lower after $24 \mathrm{~h}$; however, the expression was 5-fold higher than the mean expression level in non-treated cell suspensions. $C 4 H$ expression was similar to that observed for RAS. The expression of TAT and PAL did not significantly change until 12 and $24 \mathrm{~h}$ after the treatment of cell suspensions with yeast extract. The highest TAT and PAL expression in cell suspension cultures were observed after 72 and $24 \mathrm{~h}$, respectively.

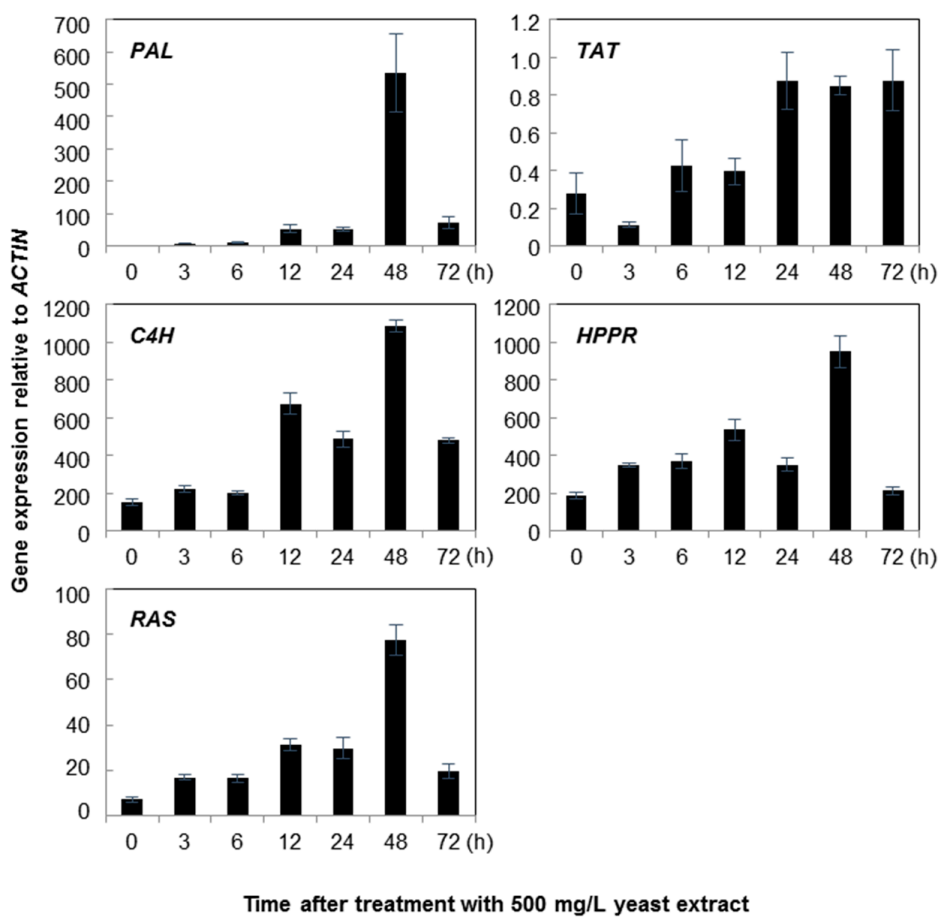

Figure 4. Time course of rosmarinic acid biosynthetic genes expression in Agastache rugosa calli treated with $500 \mathrm{mg} / \mathrm{L}$ yeast extract. Transcription levels for each gene were analyzed relative to that of ACTIN. Error bars show standard deviation values.

Treatments with silver nitrate also influenced significantly the expression levels of rosmarinic acid biosynthetic genes in cell suspensions of $A$. rugosa. RAS expression levels in cell suspension culture continuously increased from 3 to $72 \mathrm{~h}$ after the silver nitrate treatment, with levels 13.56-fold higher than those in the control treatment (Figure 5). HPPR expression exhibited a similar trend as that of $R A S$ gene. There was no considerable change in $\mathrm{C} 4 \mathrm{H}$ expression in the first $12 \mathrm{~h}$ after the treatment, showing only 1.37-fold higher transcript levels compared to those in the control group. The highest amount of $\mathrm{C} 4 \mathrm{H}$ transcripts in cell suspension culture was observed $72 \mathrm{~h}$ after the silver nitrate treatment. TAT expression showed a similar trend to that observed for the $C 4 H$ gene. TAT and PAL expression levels were slightly increased in the first $12 \mathrm{~h}$ after the silver nitrate treatment. However, these levels sharply increased after $24 \mathrm{~h}$ of treatment, and at $48 \mathrm{~h}$ after the treatment, the expression levels were 2.86-fold higher than those in the control and remained almost constant after $72 \mathrm{~h}$. The highest level of $P A L$ expression was observed after $24 \mathrm{~h}$ and exhibited expression levels 52.31-fold higher than those in the non-treated control. 


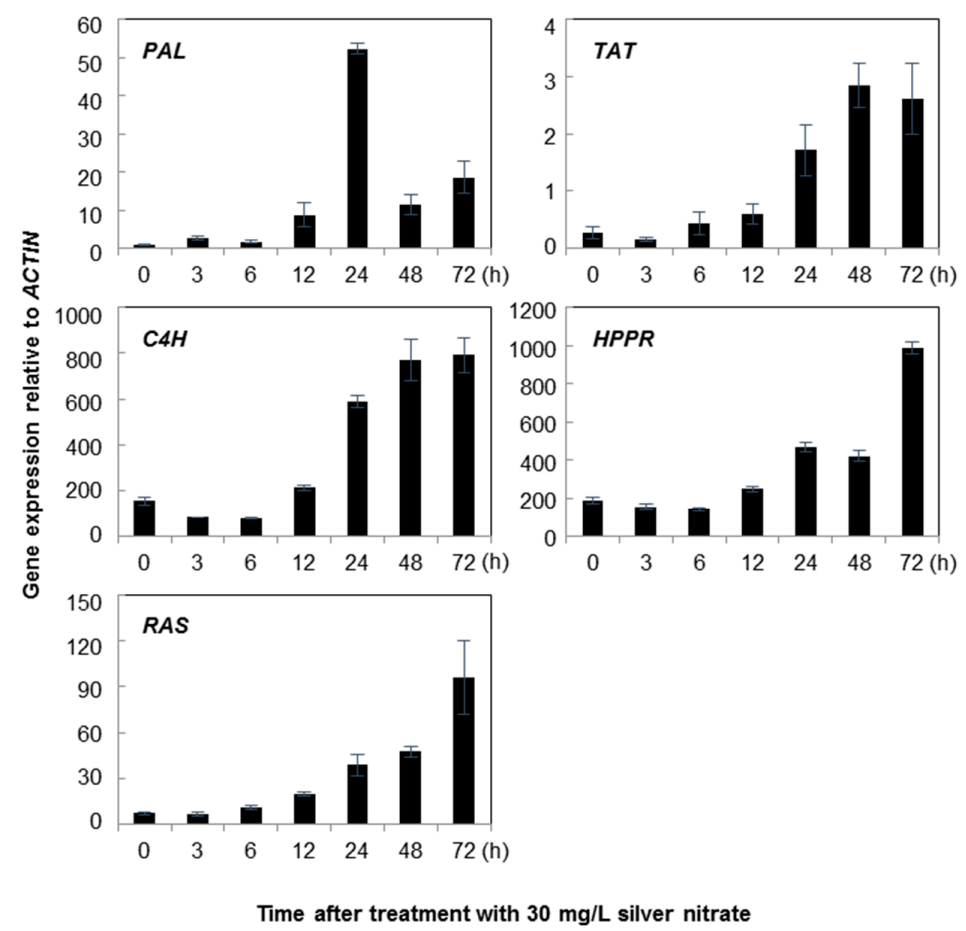

Figure 5. Time course of rosmarinic acid biosynthetic genes expression in Agastache rugosa calli treated with $30 \mathrm{mg} / \mathrm{L}$ silver nitrate. Transcription levels for each of the genes were analyzed relative to that of ACTIN. Error bars show standard deviation values.

\subsection{Quantification of Rosmarinic Acid}

Although there were differences in the contents, both yeast extract and silver nitrate treatments increased the rosmarinic acid contents at appropriate elicitor concentrations in cell suspension culture of $A$. rugosa. The amount of rosmarinic acid increased with increasing concentration of yeast extract up to $750 \mathrm{mg} / \mathrm{L}$, and then, it dramatically decreased in the callus suspension culture treated with $1000 \mathrm{mg} / \mathrm{L}$ yeast extract (Figure 6). The rosmarinic acid contents were 1.46, 2.92, and $4.53 \mathrm{mg} / \mathrm{g}$ in cell suspensions treated with 100, 250, and $500 \mathrm{mg} / \mathrm{L}$ yeast extract, respectively. The highest rosmarinic acid content of $4.98 \mathrm{mg} / \mathrm{g}$ was observed in cell suspensions treated with $750 \mathrm{mg} / \mathrm{L}$ yeast extract, which was 18.5-fold higher than the levels found in the control and 1.10-fold higher than the levels $(4.53 \mathrm{mg} / \mathrm{g})$ found in cell suspensions treated with $500 \mathrm{mg} / \mathrm{L}$ yeast extract.

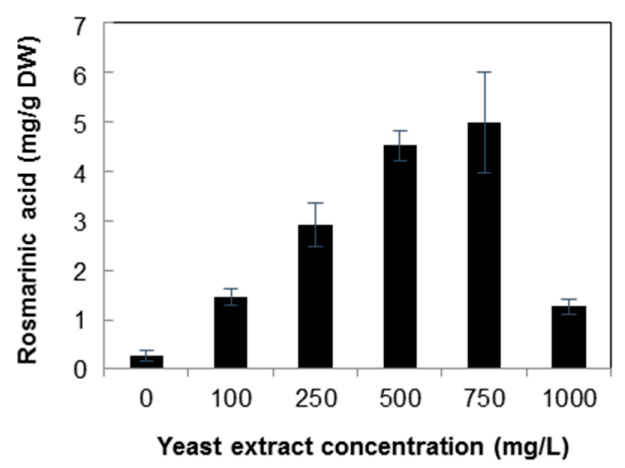

Figure 6. Content of rosmarinic acid in Agastache rugosa callus treated with various concentrations of yeast extract for $72 \mathrm{~h}$. The levels of rosmarinic acid from each sample were analyzed by high performance liquid chromatography (HPLC). Error bars show standard deviation values. DW, dry weight. 
Silver nitrate $(10 \mathrm{mg} / \mathrm{L})$ treatment did not show a significant change in the rosmarinic acid content $(0.65 \mathrm{mg} / \mathrm{g})$ (Figure 7). However, at $20 \mathrm{and} 30 \mathrm{mg} / \mathrm{L}$ silver nitrate, rosmarinic acid content increased to 1.64 and $2.94 \mathrm{mg} / \mathrm{g}$, respectively, which was 10.12-fold higher than the mean content in the non-treated control. Rosmarinic acid accumulation was stimulated by increasing the concentration of yeast extract treatments to $750 \mathrm{mg} / \mathrm{L}$, and then it noticeably decreased with $1000 \mathrm{mg} / \mathrm{L}$, whereas in the case of silver nitrate, $10 \mathrm{mg} / \mathrm{L}$ and $20 \mathrm{mg} / \mathrm{L}$ showed better production. Nevertheless, the highest detected amount of rosmarinic acid was $4.98 \mathrm{mg} / \mathrm{g}$ in cell suspensions treated with $750 \mathrm{mg} / \mathrm{L}$ yeast extract, which was 1.69-fold higher than $2.94 \mathrm{mg} / \mathrm{g}$ of rosmarinic acid found in cell suspensions treated with $30 \mathrm{mg} / \mathrm{L}$ silver nitrate. Detailed analysis confirmed treatment with both elicitors, i.e., $500 \mathrm{mg} / \mathrm{L}$ yeast extract and $30 \mathrm{mg} / \mathrm{L}$ silver nitrate, increased the rosmarinic acid concentration over time.

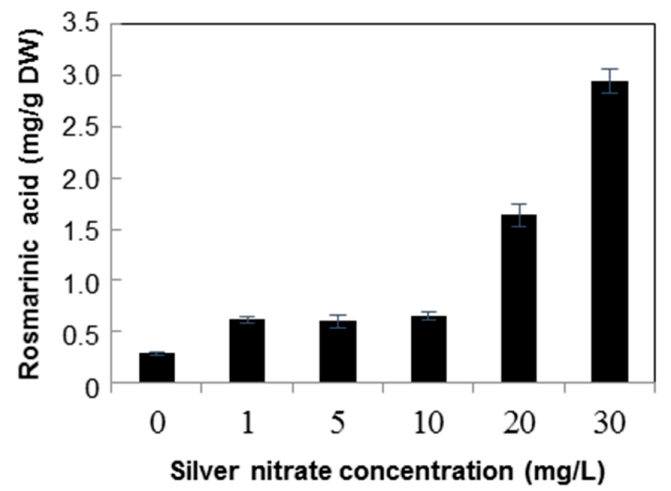

Figure 7. Contents of rosmarinic acid in Agastache rugosa callus treated with various concentrations of silver nitrate for $72 \mathrm{~h}$. The levels of rosmarinic acid in each sample were analyzed by HPLC. Error bars show standard deviation values. DW, dry weight.

Rosmarinic acid accumulation at 24, 48, and $72 \mathrm{~h}$ after yeast extract treatment was 1.12, 20.02, and $3.33 \mathrm{mg} / \mathrm{g}$ respectively. After $72 \mathrm{~h}$, the content was 6.30 -fold higher than the mean level in the non-treated control (Figure 8). However, in the silver nitrate treatment after 6, 12, and $24 \mathrm{~h}$ cultivation, the concentrations of rosmarinic acid were $0.78,1.01$, and $1.12 \mathrm{mg} / \mathrm{g}$, respectively (Figure 9). Among the treatments, the change in rosmarinic acid biosynthesis occurred faster in cell suspensions treated with silver nitrate than in those treated with yeast extract.

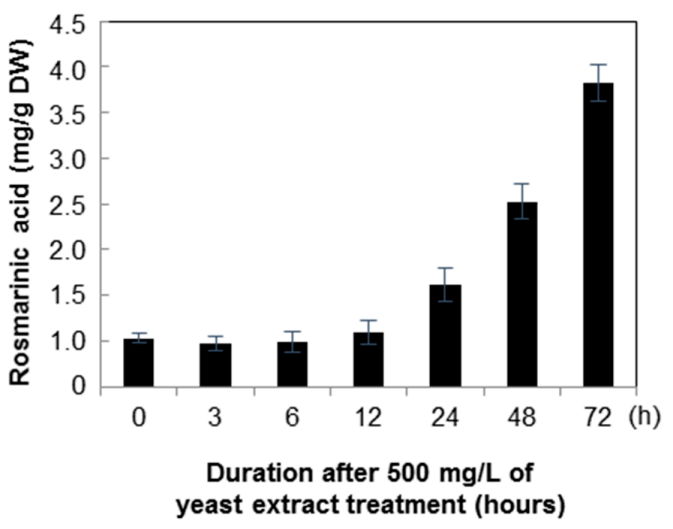

Figure 8. Time course of rosmarinic acid content in Agastache rugosa callus treated with $500 \mathrm{mg} / \mathrm{L}$ yeast extract. The levels of rosmarinic acid in each sample were analyzed by HPLC. Error bars show standard deviation values. 


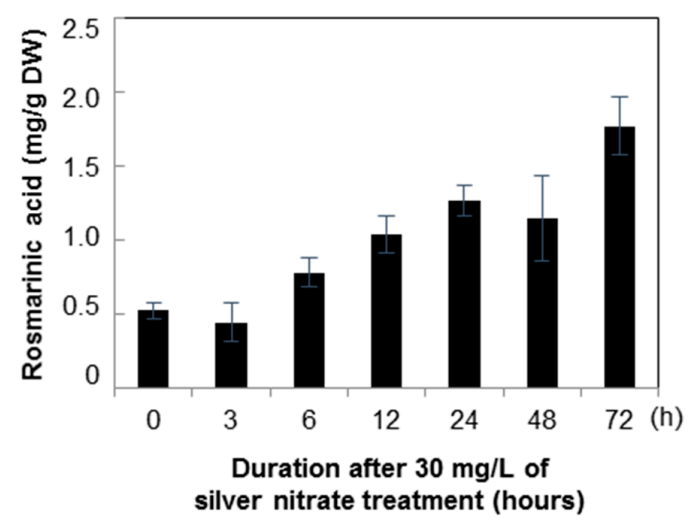

Figure 9. Time course of rosmarinic acid contents in Agastache rugosa callus treated with $30 \mathrm{mg} / \mathrm{L}$ silver nitrate. The levels of rosmarinic acid in each sample were analyzed by HPLC. Error bars show standard deviation values.

\section{Discussion}

The present study confirmed that the synthesis of rosmarinic acid in A. rugosa callus suspension cultures were stimulated by a biotic (yeast extract) and abiotic (silver nitrate) elicitor at different concentration levels. Previously, Xu et al. (2008, [25]) reported that higher amount of rosmarinic acid $(11.5 \mathrm{mg} / \mathrm{g})$ and maximum growth of callus tissue $(7.7 \mathrm{~g} / \mathrm{L})$ were obtained in $A$. rugosa, added with $2 \mathrm{mg} / \mathrm{L}$ 2,4-D and $0.1 \mathrm{mg} / \mathrm{L}$ 6-Benzylaminopurine. Kintzios et al. (2003, [26])) claimed that the leaf-derived cell suspension cultures of Ocimum basilicum accumulated rosmarinic acid up to $10 \mathrm{mg} / \mathrm{g}$ dry weight.

The results presented here corroborate previous studies on the effect of various elicitors on rosmarinic acid accumulation in different plant species. Coleus blumei supplemented with Pythium aphanidermatum enhanced the production of rosmarinic acid [24]. Kim et al. (2001) [27] demonstrated that rosmarinic acid content increased yeast elicitor, and observed rosmarinic acid mainly in the cells. Yeast extract also enhanced rosmarinic acid accumulation in Lithospermum erythrorhizon [31] and Orthosiphon aristatus [29].

Rosmarinic acid and phenolic compound production was stimulated by both elicitors (yeast extract and silver nitrate), but more significantly by yeast extract [30], and the same results were observed in the present study on A. rugosa cell suspension cultures. Our results confirmed that rosmarinic acid content was enhanced up to 18.5 -fold by the addition of $750 \mathrm{mg} / \mathrm{L}$ yeast extract to A. rugosa suspension cells compared to the levels found in non-elicited cell suspensions, and up to 10.12-fold by the treatment with $30 \mathrm{mg} / \mathrm{L}$ silver nitrate compared to that of the non-treated control. These amounts of rosmarinic acid were much higher than the previously reported levels of only 5.7-fold of those found in non-elicited cell suspensions [27].

Kim et al. (2001) [27] reported that the content of rosmarinic acid increased with cell growth during the stationary phase and then decreased gradually because of the browning process. In contrast, in lavandin cell suspensions, the amount of rosmarinic acid gradually decreased because of the stress caused by peroxidase-like enzymes [32]. However, the similar phenomenon was not observed in the A. rugosa cell suspensions in the present study because the experiments were conducted for a relatively short period. There are several biotechnological applications such as callus [1], suspension cell [25], in vitro shoot [33], and hairy root culture [34] used for the production of rosmarinic acid. Among these systems hairy root culture was more predominant in medicinal plants. Few elicitors hyperactively produce rosmarinic acid in in vitro cultures of plants [35].

Gene expression studies have shown a similar pattern as that of rosmarinic acid accumulation in A. rugosa cell suspension cultures. The expression levels of $P A L, C 4 H$ and $4 C L$ in the cell suspensions of $A$. rugosa are involved in the secondary metabolites synthesis [36]. Simmilar results were observed 
in the previous studies [24,28,29,31]. Moreover, elicitor-induced biosynthesis of rosmarinic acid and phenolic compounds in S. miltiorrhiza hairy roots correlated with TAT activity [30]. PAL and HPPR activities increased rapidly and transiently, whereas TAT activity exhibited only a slight increase. Mizukami et al. (1993) observed a similar phenomenon in the results [31]. Thus, yeast extract and silver nitrate may possess the ability to promote the rosmarinic acid biosynthetic pathway, thereby increase in rosmarinic acid production in cell suspensions. However, our results were not consistent with the results of Yan et al. (2006), which showed that rosmarinic acid and other phenolic compounds were enhanced in S. miltiorrhiza hairy root cultures using different concentrations of yeast extract and silver ions [30]. Rosmarinic acid amounts in Orthosiphon aristatus, Coleus blumei, and Lithospermum erythrorhizon were also activated using yeast extract and methyl jasmonate as elicitors $[24,28,29,31]$.

\section{Materials and Methods}

\subsection{Seed Germination and Callus Induction}

The seeds of A. rugosa were procured from Aram seed company (Seoul, Korea). For germination studies, the seeds were surface-sterilized with $70 \%(v / v)$ ethanol for $1 \mathrm{~min}$ and $4 \%(v / v)$ sodium hypochlorite solution with a few drops of $100 \%(v / v)$ Tween $10 \mathrm{~min}$, then rinsed three times in sterilized distilled water. Seven sterilized seeds were placed on $25 \mathrm{~mL}$ of half MS basal solid medium in petri dishes $(90 \times 15 \mathrm{~mm})$. The basal medium was supplemented with salts and vitamins of MS, $3 \%(w / v)$ sucrose and solidified with $0.75 \%(w / v)$ phyto agar (Duchefa, Haarlem, The Netherlands). The medium was adjusted to $\mathrm{pH} 5.8$ before adding agar, and then sterilized by autoclaving at $121^{\circ} \mathrm{C}$ for $20 \mathrm{~min}$. Then, the seeds were germinated in a growth chamber at $25^{\circ} \mathrm{C}$ under standard cool white fluorescent tubes (380 nm, SL5-SW501T-1; Sammi Elecronic Co. Ltd., Seoul, Korea) for a $16 \mathrm{~h}$ photoperiod.

The leaves obtained from 2-week-old plantlets after in vitro germination were used as explants to establish callus cultures. Leaf explants were cut aseptically at the ends into sections of approximately $7 \times 7 \mathrm{~mm}^{2}$ in size, which were then cultured in petri dishes $(90 \times 15 \mathrm{~mm})$ on B5 medium supplemented with $2.0 \mathrm{mg} / \mathrm{L} 2$,4-dichlorophenoxyacetic acid (2,4-D), $0.1 \mathrm{mg} / \mathrm{L}$ kinetin, $3 \%$ sucrose, and $0.75 \%$ plant agar. Sub-cultures of callus (1.5-2.0 g) were carried out every 2 weeks.

\subsection{Suspension Culture and Elicitor}

Cell suspensions of $A$. rugosa were grown in a 100-mL Erlenmeyer flask containing $30 \mathrm{~mL}$ of half strength MS liquid medium with $3 \%(w / v)$ sucrose, and sub-cultured every two weeks. Then the cells were transferred into a 100-mL flask containing $30 \mathrm{~mL}$ medium with 10-mL cultured cells under the optimal culture conditions. For elicitor treatment, two different kinds of elicitors, i.e., yeast extract and silver nitrate, were used. Each elicitor was dissolved in distilled water. Yeast extract solutions were prepared freshly and were added to the culture medium immediately at concentrations of $0,100,250,500,750$, and $1000 \mathrm{mg} / \mathrm{L}$ for $72 \mathrm{~h}$; silver nitrate solutions were immediately added to the culture medium at concentrations of $0,1,5,10,20$, and $30 \mathrm{mg} / \mathrm{L}$ for $72 \mathrm{~h}$. After three days, cell suspensions grown under each elicitor treatment were harvested and frozen in liquid nitrogen and stored at $-80^{\circ} \mathrm{C}$ until further use. To examine the effects of time, cell suspensions were treated under the same conditions as above for $0,3,6,12,24,48$, and $72 \mathrm{~h}$ in $500 \mathrm{mg} / \mathrm{L}$ of yeast extract or $30 \mathrm{mg} / \mathrm{L}$ of silver nitrate. The suspension cultures were maintained at $25^{\circ} \mathrm{C}$ in a shaking incubator (HB-201SF, Han Baek Scientific Co, Bucheon, Korea) at 120 rpm. Each elicitor treatment consisted of three flasks and the experiments were repeated three times.

\subsection{Total RNA Extraction and cDNA Preparation}

Total RNA was isolated from the frozen samples using a modified Trizol method. Briefly, the harvested plantlet samples were finely ground using a mortar and pestle with liquid nitrogen. 
One hundred milligrams of the ground sample was dissolved in $1 \mathrm{~mL}$ of TRI reagent ${ }^{\circledR}$ (Molecular Research Center, Inc., Cincinnati, OH, USA) together with $200 \mu \mathrm{L}$ of chloroform for phase separation. The upper aqueous phase was gently collected and centrifuged at 13,000 rpm using a micro high speed centrifuge (Micro 17TR, Hanil Science Medical, Incheon, Korea) for $15 \mathrm{~min}$ at $4{ }^{\circ} \mathrm{C}$ to pellet RNA. After centrifugation, the supernatant was discarded, and the pellet was washed with $70 \%$ ethanol and re-suspended in DEPC-treated water. Finally, the integrity of RNA was determined using a NanoVue ${ }^{\mathrm{TM}}$ Plus Spectrophotometer (GE Healthcare, Buckinghamshire, UK) and formaldehyde RNA agarose gel electrophoresis.

\subsection{Quantitative Real Time-PCR for Gene Expression Analysis}

The first strand of cDNA was synthesized using $1 \mu \mathrm{g}$ of total RNA according to the manufacturer's instructions (ReverTraAce, Toyobo, Japan). The reverse transcribed cDNA products were used as templates for gene expression analysis with gene-specific primers detailed in Table 1 . The level of expression of each gene was presented as relative expression, which is the $\mathrm{Ct}$ value of each gene compared to that of a housekeeping gene. qRT-PCR was performed on a CFX96 real time system (BIO-RAD Laboratories, Hercules, CA, USA) with the 2X Real-Time PCR Smart mix (BioFACT, Daejeon, Korea) by following these conditions: $95{ }^{\circ} \mathrm{C}$ for $15 \mathrm{~min}$, followed by 40 cycles of $95{ }^{\circ} \mathrm{C}$ for $15 \mathrm{~s}$, annealing for $15 \mathrm{~s}$ at $55^{\circ} \mathrm{C}$, and elongation for $20 \mathrm{~s}$ at $72{ }^{\circ} \mathrm{C}$. Transcript levels were normalized relative to actin as a housekeeping gene. Three replicates of each sample were used for real-time PCR analysis and the significant differences between treatments were evaluated by standard deviation.

Table 1. Primers used to qRT-PCR analysis.

\begin{tabular}{|c|c|c|}
\hline Primers & Sequences $\left(5^{\prime}\right.$ to $\left.3^{\prime}\right)$ & Amplicon Size (bp) \\
\hline $\begin{array}{l}\text { ArActin F } \\
\text { ArActin R }\end{array}$ & $\begin{array}{l}\text { ACCTCAAAATAGCATGGGGAAGT } \\
\text { GGCCGTTCTCTCACTTTATGCTA }\end{array}$ & 151 \\
\hline $\begin{array}{l}\operatorname{ArPALF} \\
\operatorname{ArPAL} R\end{array}$ & $\begin{array}{l}\text { ACGGCTCCAACGGTCATAATAAT } \\
\text { ATCCGCTTTACCTCCTCAAGGT }\end{array}$ & 108 \\
\hline $\begin{array}{l}A r C 4 H F \\
A r C 4 H R\end{array}$ & $\begin{array}{l}\text { GTTCGAGAGTGAGAATGATCCGT } \\
\text { ATAATCCTTGAACAATTGCAGCC }\end{array}$ & 157 \\
\hline $\begin{array}{l}\operatorname{ArHPPR} F \\
\operatorname{ArHPPR} R\end{array}$ & $\begin{array}{l}\text { AAGGGGATTAGGGTTACCAACACG } \\
\text { ATTCTGCCCAATCCTATGATGCC }\end{array}$ & 200 \\
\hline $\begin{array}{l}\text { ArTAT F } \\
\text { ArTAT R }\end{array}$ & $\begin{array}{l}\text { AGGCAGCAGTACCAGCCATTCTT } \\
\text { TTGACCATGAAAGCCATTGATCC }\end{array}$ & 163 \\
\hline $\begin{array}{l}\operatorname{ArRAS} F \\
\operatorname{ArRAS} R\end{array}$ & $\begin{array}{l}\text { GGCGAACTACCACACGCTGAG } \\
\text { CGATCTCGAGACGGTTATTGTCG }\end{array}$ & 161 \\
\hline
\end{tabular}

\subsection{Analysis of Phenylpropanoids by HPLC}

For high performance liquid chromatography (HPLC) analysis, samples were freeze-dried under vacuum for at least $48 \mathrm{~h}$, ground into a fine powder using a mortar and pestle; then, each $100 \mathrm{mg}$ of sample was extracted with $5 \mathrm{~mL}$ of $100 \%$ methanol for $1 \mathrm{~h}$ at $60{ }^{\circ} \mathrm{C}$ using ultrasonic waves. The phenylpropanoids, namely rosmarinic acid was extracted by methanol. After centrifugation, the supernatant was filtered through $0.45 \mu \mathrm{m}$ PVDF filter (Whatman, GE Healthcare) and the extracts were analyzed using a HPLC system (NS-4000, Futecs, Daejeon, Korea). The analysis was monitored using a UV detector at $340 \mathrm{~nm}$ and performed using a reverse phase $(\mathrm{C} 18,250 \mathrm{~mm} \times 4.6 \mathrm{~mm}, 5 \mu \mathrm{m})$ column (Prontosil, Bischoff, Germany) at $30^{\circ} \mathrm{C}$. The mobile phase was a gradient mixture of absolute methanol and water added $0.1 \%(v / v)$ acetic acid. The flow rate was maintained at $1.0 \mathrm{~mL} / \mathrm{min}$ and the injection volume of each sample was $20 \mu \mathrm{L}$. The concentration of phenylpropanoids in the samples was calculated using a standard curve. Standard compounds were purchased from Sigma-Aldrich Corporation (St. Louis, MO, USA). Mean values were obtained from three independent replicates. 


\subsection{Statistical Analysis}

For qRT-PCR and HPLC statistical analysis, data were analyzed by the statistical analysis software (SAS version 9.3, SAS Institute Inc., Cary, NC, USA). All data are given as the average mean and standard deviation of triplicate experiments. The experimental data were subjected to an analysis of variance (ANOVA), and significant differences among the means were determined using Duncan's multiple-range test.

\section{Conclusions}

In conclusion, the present study has demonstrated that the supplementation of different concentrations of yeast extract and silver nitrate elicit and stimulate the accumulation of rosmarinic acid in A. rugosa, while the elicitors enhance the expression of genes involved in the synthesis of rosmarinic acid in the phenylpropanoid pathways. The expression levels of $R A S, H P P R C 4 H, P A L$, and TAT genes confirmed that $500 \mathrm{mg} / \mathrm{L}$ and $20 \mathrm{mg} / \mathrm{L}$ concentrations of yeast extract and silver nitrate, respectively, were optimum for the synthesis of higher amounts of rosmarinic acid. This study provides the basis for further research on improving the content of rosmarinic acid in A. rugosa using elicitors and hairy root induction.

Acknowledgments: The authors extend their sincere appreciation to the Deanship of Scientific Research at King Saud University for its funding this Prolific Research Group (PRG-1437-28).

Author Contributions: S.U. Park, S.Y. Lee, and N.A. Al-Dhabi designed the experiments and analyzed the data. W.T. Park, M.V. Arasu, S.K. Yeo, J. Jeon, and J.S. Park wrote the manuscript, performed the experiments, and analyzed the data.

Conflicts of Interest: The authors declare no conflict of interest.

\section{Abbreviations}

The following abbreviations are used in this manuscript:

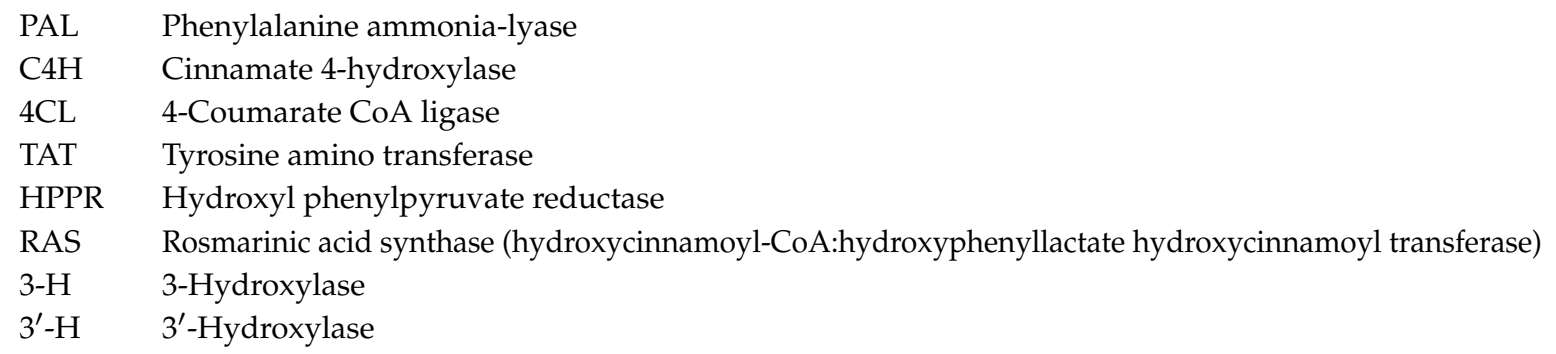

\section{References}

1. Tepe, B.; Sokmen, A. Production and optimisation of rosmarinic acid by Satureja hortensis L. callus cultures. Nat. Prod. Res. 2007, 21, 1133-1144. [CrossRef] [PubMed]

2. Sun, X.; Shen, X.; Jain, R.; Lin, Y.; Wang, J.; Sun, J.; Wang, J.; Yan, Y.; Yuan, Q. Synthesis of chemicals by metabolic engineering of microbes. Chem. Soc. Rev. 2015, 44, 3760-3785. [CrossRef] [PubMed]

3. Dornenburg, H.; Knorr, D. Strategies for the improvement of secondary metabolite production in plant cell cultures. Enzym. Microb. Technol. 1995, 17, 674-684. [CrossRef]

4. Zhong, J.J. Biochemical engineering of the production of plant specific secondary metabolites by cell suspension cultures. In Advances in Biochemical Engineering/Biotechnology; Springer: Berlin/Heidelberg, Germany, 2001; pp. 1-26.

5. Smetanska, I. Production of secondary metabolites using plant cell cultures. Food Biotechnol. 2008, 111, 187-228.

6. Discosmo, F.; Misawa, M. Eliciting secondary metabolism in plant cell cultures. Trends Biotechnol. 1985, 3, 318-322. [CrossRef] 
7. Tamari, G.; Borochov, A.; Atzorn, R.; Weiss, D. Methyl jasmonate induces pigmentation and flavonoid gene expression in Petunia corollas: A possible role in wound response. Physiol. Plant. 1995, 94, 45-50. [CrossRef]

8. Tyler, R.T.; Eilert, U.; Rijnders, C.O.M.; Roewer, I.A.; McNabb, C.K.; Kurz, W.G.W. Studies on Benzophenanthridine alkaloid production in elicited cell cultures of Papaver somniferum L. In Primary and Secondary Metabolism of Plant Cell Cultures II; Springer: Berlin/Heidelberg, Germany, 1989; pp. $200-207$.

9. Bostock, R.M.; Laine, R.A.; Kuć, J.A. Factors affecting the elicitation of sesquiterpenoid phytoalexin accumulation by eicosapentaenoic and arachidonic acids in potato. Plant Physiol. 1982, 70, 1417-1424. [CrossRef] [PubMed]

10. Conrath, U.; Domard, A.; Kauss, H. Chitosan-elicited synthesis of callose and of coumarin derivatives in parsley cell suspension cultures. Plant Cell Rep. 1989, 8, 152-155. [CrossRef] [PubMed]

11. Hong, J.J.; Choi, J.H.; Oh, S.R.; Lee, H.K.; Park, J.H.; Lee, K.Y.; Kim, J.J.; Jeong, T.S.; Oh, G.T. Inhibition of cytokine-induced vascular cell adhesion molecule-1 expression; possible mechanism for anti-atherogenic effect of Agastache rugosa. FEBS Lett. 2001, 495, 142-147. [CrossRef]

12. Song, J.H.; Kim, M.J.; Kwon, H.D.; Park, I.H. Antimicrobial activity and components of extracts from Agastache rugosa during growth period. J. Food Sci. Nutr. 2001, 6, 10-15.

13. Shin, S.; Kang, C.A. Antifungal activity of the essential oil of Agastache rugosa Kuntze and its synergism with ketoconazole. Lett. Appl. Microbiol. 2003, 36, 111-115. [CrossRef] [PubMed]

14. Gao, L.P.; Wei, H.L.; Zhao, H.S.; Xiao, S.Y.; Zheng, R.L. Antiapoptotic and antioxidant effects of rosmarinic acid in astrocytes. Pharmazie 2005, 60, 62-65. [PubMed]

15. Nam, K.H.; Choi, J.H.; Seo, Y.J.; Lee, Y.M.; Won, Y.S.; Lee, M.R.; Lee, M.N.; Park, J.G.; Kim, Y.M.; Kim, H.C. Inhibitory effects of tilianin on the expression of inducible nitric oxide synthase in low density lipoprotein receptor deficiency mice. Exp. Mol. Med. 2006, 38, 445-452. [CrossRef] [PubMed]

16. Swarup, V.; Ghosh, J.; Ghosh, S.; Saxena, A.; Basu, A. Antiviral and anti-inflammatory effects of rosmarinic acid in an experimental murine model of Japanese encephalitis. Antimicrob. Agents Chemother. 2007, 51, 3367-3370. [CrossRef] [PubMed]

17. Hernández-Abreu, O.; Castillo-España, P.; León-Rivera, I.; Ibarra-Barajas, M.; Villalobos-Molina, R.; González-Christen, J.; Vergara-Galicia, J.; Estrada-Soto, S. Antihypertensive and vasorelaxant effects of tilianin isolated from Agastache Mexicana are mediated by NO/cGMP pathway and potassium channel opening. Biochem. Pharmacol. 2009, 78, 54-61. [CrossRef] [PubMed]

18. Al-Dhabi, N.A.; Arasu, M.V.; Park, C.H.; Park, S.U. Recent studies on rosmarinic acid and its biological and pharmacological activities. Excli J. 2014, 13, 1192-1195. [PubMed]

19. Vogt, T. Phenylpropanoid biosynthesis. Mol. Plant 2010, 3, 2-20. [CrossRef] [PubMed]

20. Petersen, M.S. Characterization of rosmarinic acid synthase from cell cultures of Coleus blumei. Phytochemistry 1991, 30, 2877-2881. [CrossRef]

21. Petersen, M. Cytochrome P450-dependent hydroxylation in the biosynthesis of rosmarinic acid in Coleus. Phytochemistry 1997, 45, 1165-1172. [CrossRef]

22. Zenk, M.; El-Shagi, H.; Ulbrich, B. Production of rosmarinic acid by cell-suspension cultures of Coleus blumei. Naturwissenschaften 1977, 64, 585-586. [CrossRef]

23. Razzaque, A.; Ellis, B. Rosmarinic acid production in coleus cell cultures. Planta 1977, 137, 287-291. [CrossRef] [PubMed]

24. Szabo, E.; Thelen, A.; Petersen, M. Fungal elicitor preparations and methyl jasmonate enhance rosmarinic acid accumulation in suspension cultures of Coleus blumei. Plant Cell Rep. 1999, 18, 485-489. [CrossRef]

25. Xu, H.; Kim, Y.K.; Jin, X.; Lee, S.Y.; Park, S.U. Rosmarinic acid biosynthesis in callus and cell cultures of Agastache rugosa Kuntze. J. Med. Plants Res. 2008, 2, 237-241.

26. Kintzios, S.; Makri, O.; Panagiotopoulos, E.; Scapeti, M. In vitro rosmarinic acid accumulation in sweet basil (Ocimum basilicum L.). Biotechnol. Lett. 2003, 25, 405-408. [CrossRef] [PubMed]

27. Kim, H.K.; Oh, S.R.; Lee, H.K.; Huh, H. Benzothiadiazole enhances the elicitation of rosmarinic acid production in a suspension culture of Agastache rugosa O. Kuntze. Biotechnol. Lett. 2001, 23, 55-60. [CrossRef]

28. Mizukami, H.; Ogawa, T.; Ohashi, H.; Ellis, B.E. Induction of rosmarinic acid biosynthesis in Lithospermum erythrorhizon cell suspension cultures by yeast extract. Plant Cell Rep. 1992, 11, 480-483. [CrossRef] [PubMed] 
29. Sumaryono, W.; Proksch, P.; Hartmann, T.; Nimtz, M.; Wray, V. Induction of rosmarinic acid accumulation in cell suspension cultures of Orthosiphon aristatus after treatment with yeast extract. Phytochemistry 1991, 30, 3267-3271. [CrossRef]

30. Yan, Q.; Shi, M.; Ng, J.; Wu, J.Y. Elicitor-induced rosmarinic acid accumulation and secondary metabolism enzyme activities in Salvia miltiorrhiza hairy roots. Plant Sci. 2006, 170, 853-858. [CrossRef]

31. Mizukami, H.; Tabira, Y.; Ellis, B.E. Methyl jasmonate-induced rosmarinic acid biosynthesis in Lithospermum erythrorhizon cell suspension cultures. Plant Cell Rep. 1993, 12, 706-709. [CrossRef] [PubMed]

32. Lopez-Arnaldos, T.; Lopez-Serrano, M.; Ros, B.A.; Calderon, A.; Zapata, J. Tentative evidence of a rosmarinic acid peroxidase in cell cultures from lavandin (Lavandula $x$ intermedia) flowers. Biochem. Mol. Biol. Int. 1994, 34, 809-816. [PubMed]

33. Kračun-Kolarević, M.; Dmitrović, S.; Filipović, B.; Perić, M.; Mišić, D.; Simonović, A.; Todorović, S. Influence of sodium salicylate on rosmarinic acid, carnosol and carnosic acid accumulation by Salvia officinalis L. shoots grown in vitro. Biotechnol. Lett. 2015, 37, 1693-1701. [CrossRef] [PubMed]

34. Lee, S.; Xu, H.; Kim, Y.; Park, S. Rosmarinic acid production in hairy root cultures of Agastache rugosa Kuntze. World J. Microbiol. Biotechnol. 2008, 24, 969-972.

35. Park, S.U.; Uddin, M.R.; Xu, H.; Kim, Y.K.; Lee, S.Y. Biotechnological applications for rosmarinic acid production in plant. Afr. J. Biotechnol. 2008, 7, 4959-4965.

36. Kim, Y.B.; Kim, J.K.; Uddin, M.R.; Xu, H.; Park, W.T.; Tuan, P.A.; Li, X.; Chung, E.; Lee, J.H.; Park, S.U. Metabolomics analysis and biosynthesis of rosmarinic acid in Agastache rugosa Kuntze treated with methyl jasmonate. PLoS ONE 2013, 8, e64199. [CrossRef] [PubMed]

Sample Availability: Samples of the compounds (rosmarinic acid and tilianin) are available from the authors.

(C) 2016 by the authors; licensee MDPI, Basel, Switzerland. This article is an open access article distributed under the terms and conditions of the Creative Commons by Attribution (CC-BY) license (http://creativecommons.org/licenses/by/4.0/). 